\title{
ISLAMIC WEALTH MANAGEMENT: STRATEGIES IN SHARIA-BASED FINANCIAL PLANNING AND MANAGEMENT
}

\author{
Risanda A. Budiantoro ${ }^{1 *}$, Amalia Nur Chasanah ${ }^{2}$, Nur Rachmat Arifin ${ }^{3}$ Tamimah $^{4}$ \\ ${ }^{* 1}$ Keuangan Syariah, Fakultas Ekonomi dan Bisnis Universitas Dian Nuswantoro Semarang, \\ Jalan Imam Bonjol 207, Kota Semarang, 50131 \\ ${ }^{2}$ Manajemen Keuangan, Fakultas Ekonomi dan Bisnis Universitas Dian \\ Nuswantoro Semarang, Jalan Imam Bonjol 207, Kota Semarang, 50131 \\ ${ }^{3}$ Ekonomi Syariah, Fakultas Ekonomi dan Bisnis Islam, Universitas Islam Zainul Hasan \\ Genggong, Jl Raya Panglima Sudirman No. 360, Kec. Kraksaan 67282 \\ ${ }^{4}$ Ekonomi Syariah, Stai Miftahul Ulum Tarate Pandian Sumenep, Jl. Pesantren No 11. Tarate \\ Pandian Sumenep 69414 \\ *1 risanda.abe@gmail.com, ${ }^{2}$ amalia.nurchasanah@gmail.com, \\ ${ }^{3}$ nurrachmatarifin05@gmail.com, ${ }^{4}$ miming151297@gmail.com
}

\begin{abstract}
The research aims to formulate and implement proper wealth management based on Sharia, so, it can help in achieving individual goals in financial management. Qualitative research approaches are used with consideration of low awareness in financial planning, so, it requires in-depth analysis in the formulation and implementation of sharia-based wealth management in order to be more realistic. As a form of implementation of maqasid syariah to achieve falah in the world and the hereafter. The results of this study are the utilization of Islamic wealth management on financial planning, starting from the stages of planning, implementation, supervision and evaluation of plans, to ensure the wealth will yield the benefit in the world and in the hereafter.
\end{abstract}

\section{Keywords: Islamic Wealth Management, Financial Planning, Maqasid Syariah *Correspondent author}

\section{Introduction}

\section{I.1 Background}

Wealth is one thing that has an essential role in human life to meet the needs of life both for the world and the hereafter. In Islam, property owned by humans is only a deposit (trust) of Allah, and humans only act as managers. Prices are also used to prepare for a better future by managing assets following Islamic principles.

Today, there are still many ordinary people who do not understand the importance of how to manage wealth correctly and adequately, according to Islam. Financial planning is essential for every individual to improve welfare in everyday life. As a Muslim, we have to plan

Received: 2020-07-16 | Reviced: 2021-04-21 | Accepted: 2021-06-20

Indexed : Sinta, DOAJ, Garuda, Crossref, Google Scholar | DOI: 10.29313/amwaluna.v5i2.6428 
our life both economically and financially according to Maqashid Sharia to achieve falah.

Financial planning is one way to design how we obtain assets, spend them, develop them, and distribute them. According to Hafidhuddin and Tanjung (2003), financial planning is important in achieving a financial goal, where planning is the initial activity in a job in thinking about things related to the job to get optimal results.

There are various reasons for the importance of financial planning, including there are goals to be achieved, economic conditions that are not always good, the higher the cost of living from time to time, the physical human being will not always be healthy, and so on. The hope is that each individual can comprehensively understand planning and implementing their finances according to Islamic principles. Therefore, the research questions are formulated as follows: (1) What is the concept of property in Islam?; (2) What is the concept of Islamic financial planning?; (3) How is the implementation process in financial planning in accordance with sharia principles?

\section{I.2 Urgency (Priority) of Research}

This research is essential to do because it can provide the following benefits: a. Academic Benefits

The expected benefits from the results of this research can provide scientific contributions to the development and deepening of management science, especially Islamic wealth management, which can then be developed into economic science related to management based on applicable sharia principles. Through this research, it is expected to be able to provide a comprehensive picture so that the output gets an optimal strategy model and an overview of the reach of the concept of financial planning strategy in managing sharia-based assets.

\section{b. Practical Benefits}

The benefits that are expected from this research are essential considerations and inputs for everyone to be able to plan finances and realize wealth management to help them achieve their financial goals. The multiplier effect is expected for everyone to get financial freedom to contribute to improving the people's economy, becoming more prosperous, cultured, and based on religious values.

\section{I.3 Research Approach}

The research method is carried out using an explorative qualitative approach based on consideration of being able to identify the process of managing assets based on sharia principles comprehensively as a form of financial freedom. Due to the 
facts on the ground, public awareness in planning and realizing their wealth and finances to achieve their financial goals in the future is still low (Luther, 2018). Therefore, an in-depth analysis is needed to develop an ideal sharia-based wealth and financial planning so that it can achieve the financial goals that have been set. This is important, considering that wealth management (hifdzu mal) is one of the elements of the five elements in maqasid sharia or al dhoruriyyat al-khamsah (five general principles).

\section{I.4 Data Types and Sources}

The data used in this study are secondary data obtained from various sources, including literature, study journals, books, publication reports conducted by certain institutions that are able to support the results of this research, so that the formulation and implementation in wealth planning and Islamic finance-based finance can be more realistic.

\section{I.5 Research Conceptual Framework}

The research framework starts from the existing phenomena related to planning and managing wealth and sharia-based finance. There are still many problems that occur that have a significant impact. Therefore, a strategy is needed in planning and managing Sharia-based finance with the hope that: (1) achieving financial management based on Islamic maqasid; (2) the achievement of falah for the welfare of the world and the hereafter; (3) the achievement of benefit and benefit.

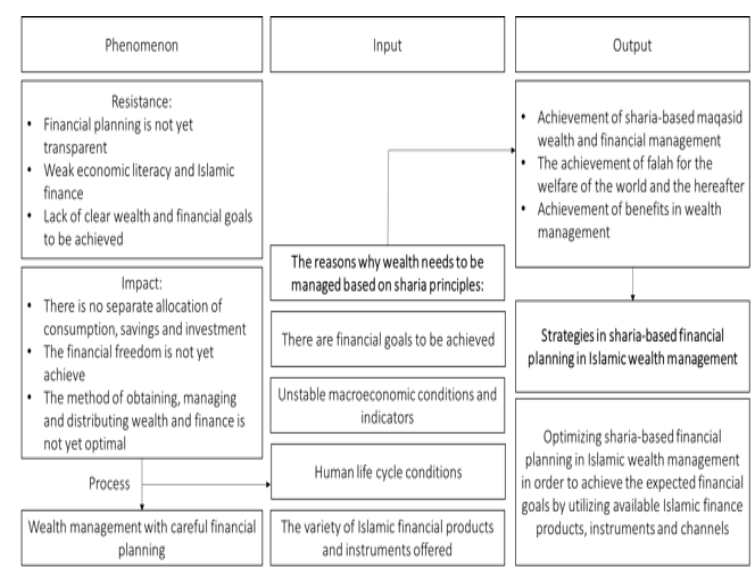

Source: Budiantoro, Putra, \& Chasanah (2020), modified

Picture 1.

Conceptual Framework for Planning and Management of Wealth and Finance Based on Sharia Principles

\section{I.6 Research focus}

The focal point of this research is the formulation and implementation of Islamic wealth management as financial planning and management based on applicable sharia principles so that it becomes more realistic. One of the real benefits that each individual gets is to plan his personal finances, to achieve predetermined goals. The emphasis lies on the process of selecting instruments in sharia-based financial planning to be added value so that what is obtained is not only happiness, prosperity, goodness, and safety in this world but also in the hereafter. Because the key to the success of this wealth management, starting from careful financial planning, financial implementation, and 
monitoring and evaluation of a comprehensive plan, the assets owned and managed will be helpful in the hereafter.

\section{Discussion}

\section{II.1 The Concept of Wealth in Islam}

According to Jaafar in Abdullah and Muhammad (2013), wealth or wealth in Islam is recognized as the basis for a meaningful life and a prerequisite for humans to carry out their dual functions as servants to Allah SWT and the caliph of humanity. Wealth or wealth in Islam belongs to Allah SWT, and humans are only mandated to manage it. With wealth, humans are expected to manage assets as well as possible for their future. In terms of acquisition, expenditure, development, and distribution, asset management must be following Islamic principles. In the Qur'an, various reasons are explained why managing assets or wealth requires careful financial planning, namely:

\section{a. Wealth as a trial}

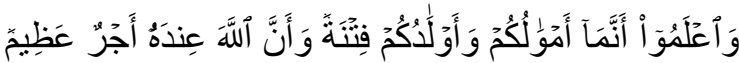
(QS. Al-Anfal (8) : 28)

Meaning: "Know well that your belongings and your children are but a trial, and that with Allah there is a mighty reward." QS. Al-Anfal (8) : 28.

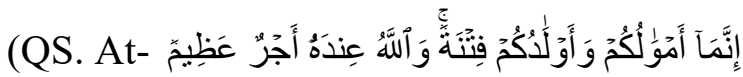
Taghaabun (64) : 15)

Meaning: "Your wealth and your children are only a test for you. There is great reward with God." QS. At-Taghaabun (64) : 15.
Drawing the red thread from the two verses, that wealth is a test of faith given by Allah to his servants. Of course, this is related to how a person obtains and uses these assets. Because ideally, following Islamic teachings, it means that the essence of love for wealth (including children) is not greater than the love for Allah and the Messenger of Allah. In religious guidance, the Messenger of Allah once gave an example related explicitly to showing his love for his daughter Fatima, "Verily Fatima is a piece of my flesh, so whoever lies to her is lying to me and whoever disturbs her will nod me" (Bukhari).

\section{b. Assets as a trust}

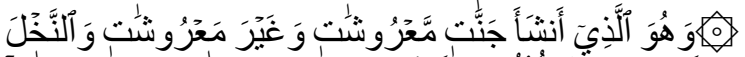

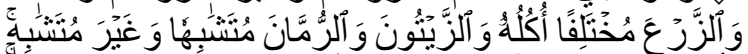

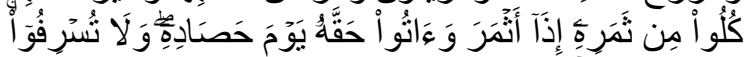

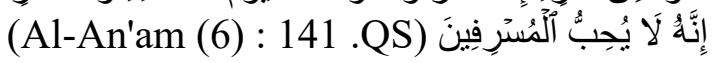

Meaning: "And He it is who causes gardens to grow, [both] trellised and untrellised, and palm trees and crops of different [kinds of] food and olives and pomegranates, similar and dissimilar. Eat of [each of] its fruit when it yields and give its due [zakāh] on the day of its harvest. And be not excessive.1 Indeed, He does not like those who commit excess." QS. Al-An'am (6) : 141.

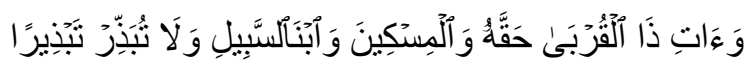
(QS. Al-Israa' (17) : 26)

Meaning: "And give the relative his right, and [also] the poor and the traveler, and do not spend wastefully." QS. Al-Israa' (17) : 26.

The context of trust in this wealth indicates that the inability of humans to 
create wealth, from what was not originally there, became something. Because the creation of wealth, in this case, is God. Humans are only allowed to manage and possibly relate to the wealth given by God to his people. This means that Allah wholly owns absolute ownership of assets so that ownership of assets for humans is only relative, limited only to carrying out the mandate to manage and utilize them following applicable Sharia provisions. The essence of managing wealth wisely will bring blessings, goodness, and safety in this world and the hereafter.

\section{c. Assets Must Be Managed In A Balanced Way (Wealth Optimization)}

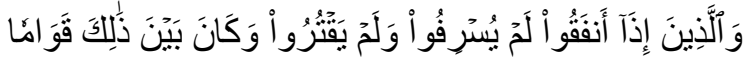
(QS. Al-Furqan (25) : 67)

Meaning: "And [they are] those who, when they spend, do so not excessively or sparingly but are ever, between that, [justly] moderate." QS. Al-Furqan (25) : 67

The mechanism for optimizing wealth is one of the essential aspects of managing assets because, without sufficient assets, one's life becomes imperfect, and there is a tendency to create criminal elements in social life. In contrast, in the opposite condition, someone who wants wealth in large amounts abundant tends to spend his time solely looking for wealth and will forget other pious deeds. So the emphasis is on optimizing wealth so that it is neither too much nor too little to get blessings in his wealth.

\section{d. Wealth plays an important role in life or worship}

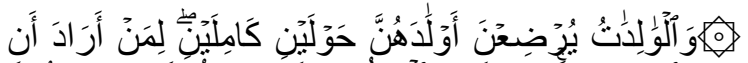

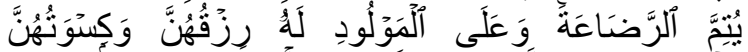

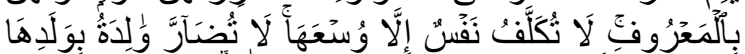

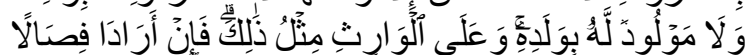

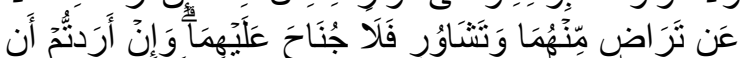

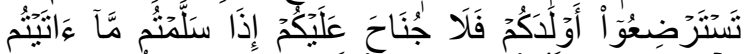

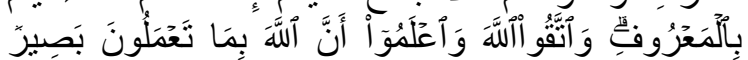

(QS. Al-Baqarah (2) : 233)

Meaning: "Mothers may nurse [i.e., breastfeed] their children two complete years for whoever wishes to complete the nursing [period]. Upon the father is their [i.e., the mothers'] provision and their clothing according to what is acceptable. No person is charged with more than his capacity. No mother should be harmed through her child, and no father through his child. And upon the [father's] heir is [a duty] like that [of the father]. And if they both desire weaning through mutual consent from both of them and consultation, there is no blame upon either of them. And if you wish to have your children nursed by a substitute, there is no blame upon you as long as you give payment according to what is acceptable. And fear Allah and know that Allah is Seeing of what you do.." QS. AlBaqarah (2) : 233

In the perspective of worship, wealth is a necessary form of capital for humans in carrying out worship because there are several forms of worship that require wealth in its implementation, such as zakat, infaq, alms, and waqf. However, in the implementation process, worship by using 
wealth is the hardest thing because of the nature of love for the property it has, considering that acquiring these assets requires more effort or, in other words, there is a fear that the assets they have will decrease. To motivate and encourage someone to quickly have this spirit of worship, Allah gives abundant rewards.

\section{II.2 Islamic Financial Planning} Concept

In a conventional context, financial planning is a process to achieve financial goals that a person has previously set through developing and carrying out a mature and comprehensive financial strategy (Ghozie, 2014). As a simple analogy, financial planning is a blueprint, which contains a detailed framework that makes it easier to implement for each business unit. This means that the more detailed the financial plan, indicating that the more precise direction, objectives, targets, programs, and financial instruments will be used to achieve the objectives of the financial plan. Conventional financial planning is also known as financial freedom.

The same thing was also expressed by Ahmed and Salleh (2016), where financial planning is a process of determining whether and how a person can fulfill life goals in the future through four key elements of proper financial resource management, including:
Table 1.

Four Elements in Financial Planning

\begin{tabular}{|c|c|}
\hline $\begin{array}{l}\text { Elements of } \\
\text { Financial } \\
\text { Planning }\end{array}$ & Definition \\
\hline $\begin{array}{c}\text { Money } \\
\text { Management }\end{array}$ & $\begin{array}{l}\text { Decisions in asset } \\
\text { management to achieve a } \\
\text { decent life through cash } \\
\text { flow management and } \\
\text { proper use of credit. Its } \\
\text { implementation } \\
\text { emphasizes effective cash } \\
\text { management, starting } \\
\text { from estimating, } \\
\text { recording, and evaluating } \\
\text { income, savings, and } \\
\text { expenses. }\end{array}$ \\
\hline $\begin{array}{l}\text { Emergency } \\
\text { Planning }\end{array}$ & $\begin{array}{l}\text { The primary tool in } \\
\text { anticipating unexpected } \\
\text { events is by allocating } \\
\text { emergency funds or } \\
\text { taking insurance. The } \\
\text { thing that needs to be } \\
\text { considered in selecting the } \\
\text { proper instrument is to } \\
\text { provide a sense of security } \\
\text { and comfort. The rule of } \\
\text { thumb is that daily } \\
\text { expenses cannot be mixed } \\
\text { with unforeseen events, so } \\
\text { ideally, someone has an } \\
\text { allocation for the } \\
\text { unexpected with the } \\
\text { details of covering three } \\
\text { to six months of daily } \\
\text { household expenses. }\end{array}$ \\
\hline $\begin{array}{l}\text { Investing for } \\
\text { Goals }\end{array}$ & $\begin{array}{l}\text { Investments in financial } \\
\text { planning are aimed at } \\
\text { long-term goals } \\
\text { (particularly in education } \\
\text { and retirement planning) } \\
\text { in the form of tangible } \\
\text { and financial assets. }\end{array}$ \\
\hline $\begin{array}{c}\text { Transference } \\
\text { or Estate } \\
\text { Planning }\end{array}$ & $\begin{array}{l}\text { The process for } \\
\text { developing a financial } \\
\text { plan for managing and } \\
\text { distributing assets after } \\
\text { death, in this context, is a } \\
\text { will. }\end{array}$ \\
\hline
\end{tabular}


Sources: Ahmed and Salleh (2016), Nawi (2018)

Whereas in Islamic financial planning, it shows the process of planning a better life by planning, selecting and managing wealth and finances in life by following the rules and demands of Islamic teachings to achieve short, medium, and long term life goals both for blessings in the world and in the world. hereafter (Mingka and Trisandi, 2010).

Financial planning aims to preserve one of the five basic needs, namely, the preservation of wealth. There are five main dimensions in the preservation of wealth (Dasuki and Bouheraoua, 2011), namely the preservation of wealth through protection and ownership; preservation of wealth through its acquisition and development; preservation of wealth from damage; protection of wealth through its circulation; and the preservation of wealth through the protection of its value.

The ultimate goal in the concept of Islamic financial planning is to make falah, which focuses not only on life in this world but also for life in the hereafter. This is following the word of God, namely:

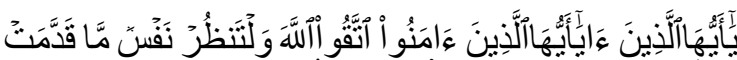

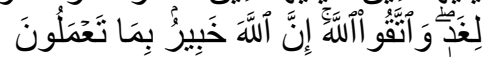

(QS. Al-Hasyr (59) : 18)

Meaning: "O you who have believed, fear Allah. And let every soul look to what it has put forth for tomorrow - and fear Allah.
Indeed, Allah is Aware of what you do". QS. Al-Hasyr (59) : 18.

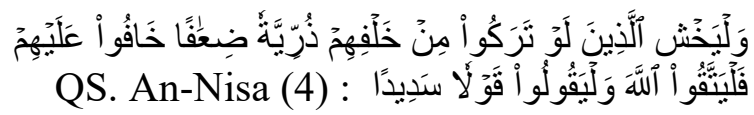

Meaning: "And let those [executors and guardians] fear [injustice] as if they [themselves] had left weak offspring behind and feared for them. So let them fear Allah and speak words of appropriate justice." QS. An-Nisa (4) : 9

In addition, financial planning is also carried out to avoid usury, ghoror, maysir, and dzalim both in seeking income and spending this wealth. With mature Islamic financial planning, it is hoped that it will avoid wasteful nature and prioritize spending its wealth in the way of goodness. Worship is one of the main concepts in Islamic financial planning.

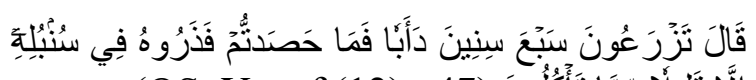

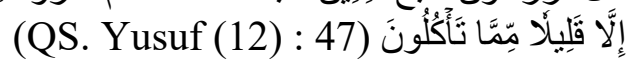

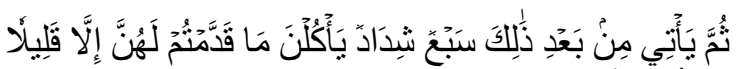

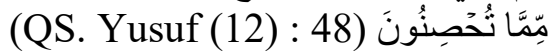

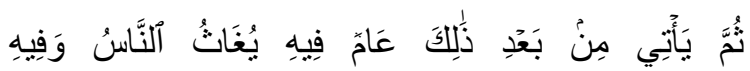

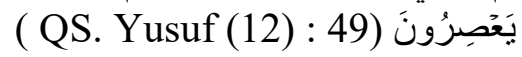

Meaning: "Yusuf said, "You will plant for seven years consecutively; and what you harvest leave in its spikes, except a little from which you will eat. Then will come after that seven difficult [years] which will consume what you advanced [i.e., saved] for them, except a little from which you will store. Then will come after that a year in which the people will be given rain and in which they will press [olives and grapes]". QS. Yusuf (12) : 47-49. 
The above verse explains that we should save during good times like good harvests in preparation for bad times like drought periods as a Muslim. As for the individual, an event that is certain to occur is death. Thus, proper and appropriate financial planning is needed to reduce difficulties in the future.

Islamic financial planning includes income, expenditure, debt management, protection (risk management), investment, zakat, alms, charity, and waqf (Abdullah, Derus, \& Al-Malkawi 2015; Safari, Mansori \& Sesaiah, 2016, 2017; Putri , 2016). The benefits obtained from the existence of a mature Islamic financial planning, among others: (1) ensure that all basic needs are met and as a reference in the preparation of financial planning; (2) as an evaluation of financial management by examining financial conditions in achieving financial goals; and (3) as an encouragement (motivation). Islamic financial planning is part of Maqashid Sharia. The five elements contained in Maqashid Sharia, namely the maintenance of religion (hidfdhun-din), the maintenance of the soul (hifdhul-hayah), the maintenance of the mind (hifdhul-'aql), maintenance of offspring (hifdhul-nasl), and maintenance of property (hifdhul-maal). Financial planning is one way to protect the assets we have so that the form of Islamic financial planning is an ideal form that describes the suitability of the objectives to be achieved (Jazil, 2017) (see Figure 2).

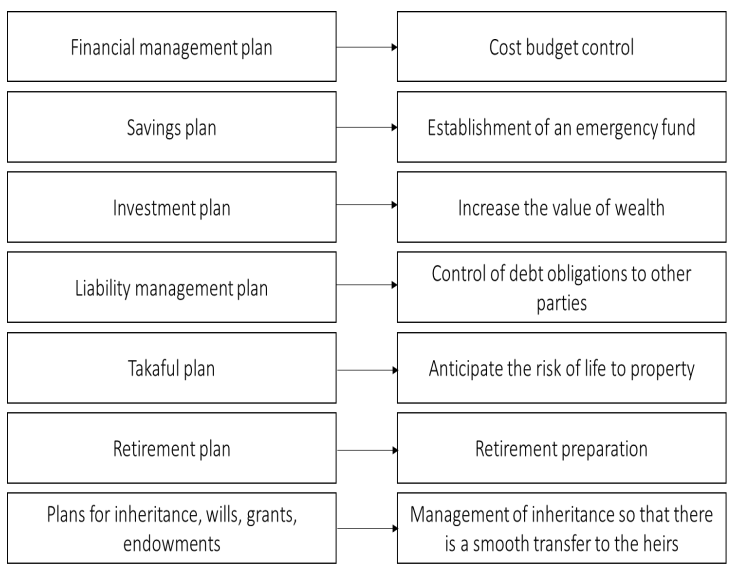

Sumber: Iqbal (2008), Amanda, Possumah, Firdaus (2018) dimodifikasi

Figure 2.

\section{Financial Plans and Fit for Purpose}

According to Oluwanisola and

Wahab (2014), several instruments must be met in setting the ideal financial plan to realize the goals that have been set previously, including:

Table 2.

Instruments that Must Be Fulfilled in a Sharia Financial Plan

\begin{tabular}{|l|l|}
\hline Instrument & \multicolumn{1}{c|}{ Explanation } \\
\hline $\begin{array}{l}\text { Setting } \\
\text { financial } \\
\text { goals }\end{array}$ & $\begin{array}{l}\text { The process for setting and } \\
\text { prioritizing realistic } \\
\text { financial goals and } \\
\text { objectives with an } \\
\text { appropriate time frame and } \\
\text { a clearly defined level of } \\
\text { risk tolerance }\end{array}$ \\
\hline $\begin{array}{l}\text { The process of gathering a } \\
\text { wealth of relevant, accurate } \\
\text { and up-to-date information } \\
\text { is in line with financial } \\
\text { data }\end{array}$ & $\begin{array}{l}\text { objectives. The more } \\
\text { complex the situation and } \\
\text { the goals to be achieved, } \\
\text { the more challenging the } \\
\text { risk in gathering } \\
\text { information }\end{array}$ \\
\hline
\end{tabular}




\begin{tabular}{|l|l|}
\hline Analyze & $\begin{array}{l}\text { The process of analyzing } \\
\text { and evaluating data begins } \\
\text { after sufficient information } \\
\text { has been collected. This } \\
\text { step aims to determine the } \\
\text { current position compared } \\
\text { to the financial goals to be } \\
\text { achieved }\end{array}$ \\
\hline $\begin{array}{l}\text { Develop } \\
\text { plans to } \\
\text { achieve } \\
\text { goals }\end{array}$ & $\begin{array}{l}\text { Develop a specific plan } \\
\text { and make many } \\
\text { alternatives that must be } \\
\text { explored and considered } \\
\text { such as who should do } \\
\text { what, when, and what } \\
\text { resources are needed }\end{array}$ \\
\hline $\begin{array}{l}\text { Implement } \\
\text { the plan }\end{array}$ & $\begin{array}{l}\text { Plans that have been drawn } \\
\text { up must be implemented. } \\
\text { The success of a plan is } \\
\text { highly dependent on one's } \\
\text { commitment to } \\
\text { implementing the plan. }\end{array}$ \\
\hline $\begin{array}{l}\text { Supervise } \\
\text { the } \\
\text { execution } \\
\text { of the plan }\end{array}$ & $\begin{array}{l}\text { The financial planning } \\
\text { process is dynamic and } \\
\text { requires constant } \\
\text { monitoring and review. } \\
\text { This process should } \\
\text { involve tracking the } \\
\text { progress and performance } \\
\text { of the implementation of } \\
\text { the plan }\end{array}$ \\
\hline Source: Oluwang and Wana (2014)
\end{tabular}

Source: Oluwanisola and Wahab (2014)

After all the elements are met, then financial planning in Islamic principles can be carried out ideally. However, there are still several components that must be considered, primarily related to controlling in financial management, including:

a. Allocation of a healthy income, income earned must be allocated based on priorities, namely (Ghozie, 2014): 1) zakat, which aims to purify wealth and share it with those in need; 2) insurance to protect themselves and their families from unexpected things, 3) present consumption, which is setting aside funds for the necessities of life now; 4) future spending, namely saving for plans; and 5) invest in the future even after retirement.

b. Financial intelligence, making a financial plan requires a good strategy to manage the assets owned. The strategies needed to fulfill life, among others (Suwiknyo, 2009): 1) make financial records by providing a particular book to record every expenditure and income every week; and 2) save money and separate it in envelopes to the needs that have been previously planned. In planning finances, we must also be able to separate which are our needs and wants. As a good Muslim, Allah SWT has forbidden his people to do extravagance.

c. financial life cycle, it is hoped that later it will make it easier to make financial decisions such as what is needed or not from each of our life cycles. This is because, with increasing age, the priorities of the financial plan also change.

d. Compiling an expenditure plan, in planning finances, we must be able to make a priority scale so that expenses can be adequately regulated. Islam stipulates that in spending one's property 
or wealth, one should not be extravagant or excessive.

\section{II.3 Implementation of Islamic Financial}

\section{Planning}

When a person plans his finances well, it will help achieve financial freedom to achieve financial freedom. This is justified by Ghozie (2014), where good and correct financial planning will be reflected in the allocation of income and expenses according to each individual's priority goals so that financial management is ideal. Where these financial priorities can be managed and budgeted in several elements, including:

a. Current consumption, the form of utilization of wealth

b. Saving, by setting aside income to be used for future consumption

c. Investment, a form of accumulation of wealth

d. Zakat, a form of purification of wealth

e. Guarantee (insurance), a form of property protection

In order to carry out an ideal financial planning, it is done in the following ways:

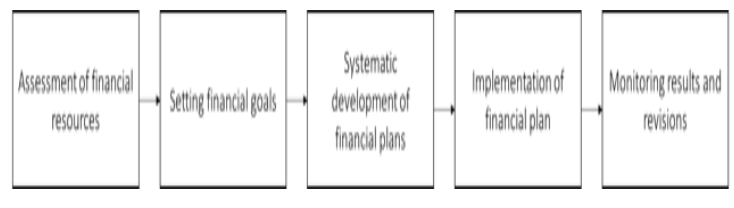

Sumber: Mukhlisin, (2013), modified

Figure 3.

Steps in Financial Planning
In this case, financial planning is to create financial freedom, where a person can determine his financial goals for the future. From an Islamic perspective, this financial planning refers to lawful and sources and their use for personal and social interests. The percentage process in managing assets with Islamic financial planning is divided into three categories (Choirunnisak, 2017): (1) $1 / 3$ part for everyday life; $(2)^{1 / 3}$ share for the struggle in the way of Allah; $(3)^{1 / 3}$ parts for future use. Where coherently and systematically, financial planning in Islam is formulated as follows:

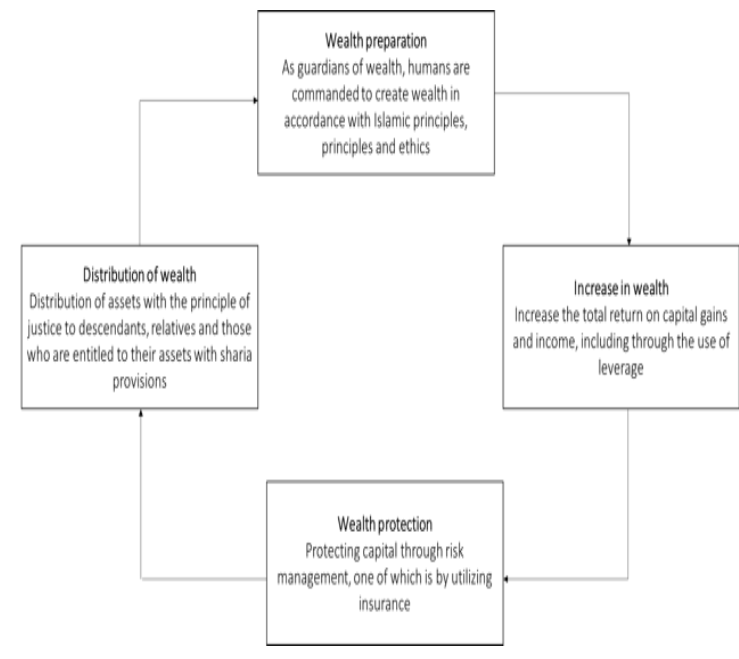

Sumber: Jazil, (2017)

Figure 4.

Islamic Financial Planning Cycle

The form of implementation of this financial planning will be influenced by three aspects (Mustamin, 2018), namely: (1) Maslahah, is a benefit followed by blessing because it remains in the corridor of Sharia as a reward from Allah; (2) falah, means a blessed maslahah where the wealth we have 
is eternal (meaning success in managing wealth to achieve maslahah in this world and the hereafter); (3) Blessing, is happiness that is measured materially and non-materially obtained in this world and the hereafter.

Regarding the implementation mechanism of Islamic wealth management through sharia-based financial planning mechanisms, there are relatively significant differences from those that occur in the conventional concept, namely the existence of a wealth purification process. So that the stages of implementing sharia-based financial planning are shown in Table 3 below:

Table 3. Orientation of Sharia-Based Financial Planning

\begin{tabular}{|c|c|c|}
\hline $\begin{array}{l}\text { Orientati } \\
\text { on }\end{array}$ & Base & Information \\
\hline $\begin{array}{l}\text { Wealth } \\
\text { creation }\end{array}$ & $\begin{array}{l}\text { QS. Al- } \\
\text { Jumu'ah } \\
(62): 4 \text { and } \\
\text { 10; QS. An- } \\
\text { Nisa (40): } \\
32\end{array}$ & $\begin{array}{l}\text { Individuals } \\
\text { carry out the } \\
\text { mechanism for } \\
\text { creating wealth } \\
\text { through } \\
\text { business } \\
\text { (charity) or } \\
\text { work } \\
\text { (Maliyah) } \\
\text { which is lawful } \\
\text { and tahyib } \\
\text { following what } \\
\text { has been } \\
\text { prescribed. In } \\
\text { essence, the } \\
\text { best way to } \\
\text { create wealth } \\
\text { is to use one's } \\
\text { own business. }\end{array}$ \\
\hline $\begin{array}{l}\text { The } \\
\text { accumulat }\end{array}$ & $\begin{array}{l}\text { QS. Al- } \\
\text { Baqarah } \\
(2): 188 \text { and }\end{array}$ & $\begin{array}{l}\text { In } \\
\text { accumulating } \\
\text { wealth, in }\end{array}$ \\
\hline
\end{tabular}

\begin{tabular}{|c|c|c|}
\hline $\begin{array}{l}\text { ed amount } \\
\text { of treasure }\end{array}$ & $\begin{array}{l}\text { 275; QS. } \\
\text { Ali 'Imran } \\
\text { (3): 130; } \\
\text { QS. An } \\
\text { Nisaa' (4): } \\
\text { 161; QS. } \\
\text { Al-Maidah } \\
\text { (5): 90; QS. } \\
\text { Ar-Rum } \\
\text { (30): } 39\end{array}$ & $\begin{array}{l}\text { Islam it is } \\
\text { permissible to } \\
\text { carry out } \\
\text { investment } \\
\text { activities that } \\
\text { comply with } \\
\text { sharia } \\
\text { provisions, so } \\
\text { it is advisable } \\
\text { to choose } \\
\text { sharia-based } \\
\text { financial } \\
\text { instruments } \\
\text { and avoid } \\
\text { activities such } \\
\text { as maysir and } \\
\text { gharar and } \\
\text { usury and } \\
\text { haram. }\end{array}$ \\
\hline $\begin{array}{l}\text { Property } \\
\text { protection }\end{array}$ & $\begin{array}{l}\text { QS. Al- } \\
\text { Baqarah (2) } \\
: 185 ; \\
\text { QS. Al- } \\
\text { Hasyr (59): } \\
\text { 18; } \\
\text { QS. Al- } \\
\text { Quraish } \\
(106): 4\end{array}$ & $\begin{array}{l}\text { One form of } \\
\text { property } \\
\text { protection } \\
\text { according to } \\
\text { Islam, namely } \\
\text { risk } \\
\text { management } \\
\text { and Islamic } \\
\text { insurance } \\
\text { (takaful). So } \\
\text { that all forms } \\
\text { of Islamic } \\
\text { investment } \\
\text { instruments } \\
\text { must be able to } \\
\text { avoid gharar } \\
\text { (uncertainty). }\end{array}$ \\
\hline $\begin{array}{l}\text { Property } \\
\text { distributio } \\
\text { n } \\
\text { wealth }\end{array}$ & $\begin{array}{l}\text { QS. Al- } \\
\text { Baqarah } \\
\text { (2): 262; } \\
\text { QS. Ali } \\
\text { Imran (3) : } \\
\text { 92; } \\
\text { QS. At- } \\
\text { Taubah (9): } \\
60 \text { and 103 }\end{array}$ & $\begin{array}{l}\text { The } \\
\text { distribution of } \\
\text { assets means } \\
\text { distributing } \\
\text { assets to those } \\
\text { who are } \\
\text { entitled to } \\
\text { receive them, } \\
\text { so that in this } \\
\text { case there is an } \\
\text { effort to } \\
\text { distribute }\end{array}$ \\
\hline
\end{tabular}




\begin{tabular}{|l|l|}
\hline & wealth (not \\
& centered on a \\
particular \\
group). One of \\
the instruments \\
in Islam, \\
which plays a \\
role in the \\
distribution of \\
wealth is \\
tithing, giving \\
alms and \\
giving infaq. \\
\hline
\end{tabular}

Source: Budiantoro, Putra \& Chasanah, (2020):

\section{Conclusion}

From all the problems and discussions related to the planning and management of wealth and finance based on Sharia principles, the following conclusions are drawn:

The Sharia recognizes wealth or wealth as the basis for a meaningful life and a prerequisite for human beings to carry out their dual function as servants to Allah and the caliph of humankind. With wealth, humans are expected to manage assets as well as possible for their future. In terms of acquisition, expenditure, development, and distribution, asset management must be following Islamic principles. Good financial planning is needed to manage assets for several reasons: assets as a trial, assets as a trust, assets must be managed in a balanced way, and assets play an important role in life or worship.
Financial planning based on sharia principles is the process of determining whether and how a person can fulfill life goals in the future through proper management of financial resources in line with applicable Sharia principles. Excellent and correct sharia principle financial planning will be reflected in the allocation of income and expenses according to each individual's priority goals so that financial management is ideal for achieving optimal benefits and problems.

There are four critical elements in implementing financial planning: Money Management, Emergency Planning, Investing for Goals, and Transference or Estate Planning. The difference between conventional and Islamic financial planning lies in the focus of the end goal. If conventional financial planning only focuses on achieving prosperity globally, Islamic financial planning focuses on life in this world and the hereafter. Financial planning in Islam includes Islamic income, Islamic expenditure, debt management, protection (risk management) in Islam, investment, zakat, alms, charity, and waqf. Five steps must be taken in financial planning: an assessment of current financial resources; defining current financial goals; systematic development of financial plans; implementation of financial plans; and 
monitoring results and revising goals and plans as needed.

\section{Bibliography}

Abdullah, Amalina, dan Jumaina Muhammad. 2013. "Ethical Values in Islamic Financial Planning". Jurnal Pengurusan, (38): 133-140.

Abdullah, Naziruddin, Alias Mat Derus, Husam-Aldin Nizar Al-Malkawi. 2015. "The Effectiveness Of Zakat In Alleviating Poverty and Inequalities: A Measurement Using A Newly Developed Technique". Humanomics, 31 (3): 314-29.

Ahmed, Habib dan Ak Md Hasnol Alwee Pg Md_Salleh. 2016. "Inclusive Islamic Financial Planning: A Conceptual Framework". International Journal of Islamic and Middle Eastern Finance and Management, 9 (2): 170-89.

Amanda, Farisah, Bayu Taufiq Possumah, Achmad Firdaus. 2018. "Consumersm in Personal Finance: An Islamic Wealth Management Approach". AlIqtishad: Jurnal Ilmu Ekonomi Syariah, 10 (2): 325-40.

Budiantoro, R., Fitroh Sukono Putra, F., \& Chasanah, A. (2020). "Wealth Allocation Framework: Dalam Kerangka Maslahah". Benefit: Jurnal Manajemen dan Bisnis, 5(1): 96-108.

Choirunnisak. 2017. "Konsep Pengelolaan Kekayaan dalam Islam". Islamic Banking, 3 (1): 27- 44.

Dusuki, Asyraf Wajdi and Said Bouheraoua. 2011. "The Framework of Maqasid Al-Shari'ah and Its Implication For Islamic Finance". Islam and Civilisational Renewal, 2 (2): 316-36

Ghozie, Prita Hapsari. 2014. Make It Happen (Buku Pintar Rencana Keuangan Untuk Mewujudkan
Mimpi). Jakarta: PT. Gramedia Pustaka Utama.

Hafidhuddin, Didin dan Hendri Tanjung. 2003. Manajemen Syariah dalam Praktik. Jakarta: Gema Insani Press.

Iqbal, M. 2008. Dinar Solution. Jakarta: Gema Insani Press.

Jazil, Thuba. 2017. Perencanaan Keuangan Islami, Why Not?, (online), https://tazkia.ac.id/2017/09/24/perenc anaan-keuangan-islami-why-not/,

Luther, R., Linda Jane Coleman, Mayuresh Kelkar dan Gregory Foudray 2018. "Generational Differences In Perceptions of Financial Planners". Journal of Financial Services Marketing: 1-16.

Mingka, Agustianto dan Luthfi Trisandi. 2010. Figh Keuangan Syariah. Jakarta: Muda Mapan Publishing.

Mukhlisin, Murniati. 2013. Sakinan Finance (Solusi Mudah Mengatur Keuangan Keluarga Islami). Solo: Tinta Medina.

Nawi, Hafizah Mat. 2018. "Financial Planning Framework: Empirical Evidence on Muslim Households in Malaysia". Canadian Social Science, 14(5): 11-16.

Oluwanisola, Abdul Azeez, dan Abdul Wahab. 2014. "A Review of Islamic Financial Planning Process in Oman and Nigeria". International Journal of Management Sciences, 2 (8): 383-90.

Putri, Ida Kurnia. 2016. "Financial Planning For Islamic Economics Students In Yogyakarta." Journal of Islamic Economics Lariba, 2 (1): 17-24.

Safari, Meysam, Shaheen Mansori and Stephen Sesaiah. 2016. Personal financial planning industry in Malaysia: a market survey. The Journal of Wealth Management, 18(4): 29-35. 
Safari, Meysam, Shaheen Mansori and Stephen Sesaiah, 2017. Generation difference in hiring financial planners in Malaysia. International Journal of Bank Marketing, 35(4), 583-95.

Suwiknyo, Dwi. 2009. Tarbiyah Finansial. Yogyakarta: Diva Press. 